\title{
The Application Of Coaching İn The Preparation Of Employees For Work Performance
}

\author{
Marta Matulcikova, Ass. Prof., PhD \\ Daniela Brevenikova, Ass. Prof., PhD
}

University of Economics in Bratislava, Slovak Republic

doi: 10.19044/esj.2016.v12n4p19 URL:http://dx.doi.org/10.19044/esj.2016.v12n4p19

\begin{abstract}
The aim of the present paper based on theoretical and empirical analysis is the description and evaluation of benefits of coaching in education in organizations in the Slovak Republic. Our intention is to work out the issue of coaching from the aspect of individual coaching, group coaching and team coaching, as well as from the perspective of understanding the role of coaching as part of leading. The present paper contains partial results of the research conducted under the first stage of work on the research project KEGA 014EU-4/2016 - "Preparation of the content and structure of courses focused on the development of basic business knowledge and skills of graduates from non-economic health service fields of study". Results presented in the paper relate to the application of coaching in institutions employing respondents of the research and to types and kinds of coaching. The research was conducted by means of the interview method and the questionnaire method. The data collection was held in two stages (each containing several rounds) in order to obtain respondents' responses of high information value.
\end{abstract}

Keywords: Coaching, health service field of study, corporate education, work performance, human resources management

\section{Introduction}

Managers and in particular personnel officers often deal with problems related to increasing employee performance, as well as with the choice of criteria for filling some job position with optimum qualification. Research confirms that the suitability of an individual for the performance of some specific activity need not always rest in the qualification achieved; likewise important are also psychic capabilities, character and intelligence properties, emotional intelligence properties, etc. In most cases, they achieve required knowledge, skills, and aptitudes by means of a continual education 
process, in which various methods are applied. In recent years, coaching has become an important method, used in particular in human resources management of individual organisations. Its boom started in the nineties of the previous century and has continued to date. During these years, coaching has been through numerous innovations, and from the sports environment it first spread into managerial environment, and finally also into the counselling process.

Coaching may be described as a way of dealing with people, as the way of developing thinking and acting; it is part of leading people. Its essence is to support an employee's development and lead the employee to an independent or competent performance of increasingly difficult work assignments and duties. It is the reverse of commanding and control, while its participants the coach and the client, are equals. In managerial coaching, we continue referring to the superior - subordinate relationship, which results from the position that they occupy in society. Therefore, we can say that despite the fact that the participants are in the superior - subordinate work relationship, they are able to express their personal opinions as equal partners in the coaching process.

Management of further education is an interdisciplinary, cross-border discipline, bordering on management and andragogy. A continuous further education of employees carried out concurrently with the performance of working activities creates a pre-requisite for employer entity's competitiveness and employee personal development.

Based on theoretical and empirical analysis, the aim of the present paper is the description and evaluation of benefits of coaching in education in organizations in the Slovak Republic. Our intention is to work out the issue of coaching from the aspect of individual coaching, group and team coaching, as well as from that of the understanding of the role of coaching as part of leading. The fulfilment of important assignments in the learning process, in the development of creativity as well as in supporting effective communication is amplified by coach's personality. Coaching respects a person's individuality, strengthens self-confidence and assists in creating the corporate culture in which an employee is responsible for work results.

The present paper is a presentation of partial outcomes of the research conducted under the first stage of work on the research project KEGA 014EU-4/2016 - " Preparation of the content and structure of courses focused on the development of basic business knowledge and skills of graduates from non-economic health service fields of study". Results focus on presenting experience and needs for the development of further education via coaching and its influence on the employee performance. 


\section{Development of Human Resources in Organisations by Means of Coaching:}

A permanent increase in employees' knowledge and abilities is considered an efficient means of achieving competitiveness. For this reason, investment in employees is viewed as seriously as the investment in operation and facilities. Dealing with matters of conception of professional education seems to be a matter of an enterprise's very existence. Corporate education is linked directly to its aims and tasks. This statement can be supported with the following arguments:

- Strategic relationship between quality and quantity of production and the level of productivity of labour on the one hand and the level of theoretical and practical employee qualifications on the other hand;

- Continuous growth in home and international competition, new technologies and restructuring of the labour market.

Further corporate education is carried out as:

- Adaptation education, the aim of which is to involve and train newly accepted employees (Čihovská, 2000);

- Further qualification education focused on the professional growth and increasing the so far achieved qualification (this is the case of increase in qualification in a given field);

- Requalification education (serves for acquiring the chance to do another job in an enterprise, if the existing (present) qualification does not correspond to requirements placed on the performance of work activities).

Methods of education, in particular those that result in the employees' independent and competent performance of increasingly demanding tasks, play an important role in corporate education. Coaching, which has been through numerous innovations, is not a new method; it has been known for over 2000 years and its roots are in the learning concepts; it has worked out the Socratic approach to learning. Coaching has recently become a significant education method, whose boom started in the nineties of the twentieth century and has continued to date.

Coaching can be described both as a relation and process, in which the coach helps the coached in reaching their visions, aims and in fulfilling their wishes. This method leads the coached to taking over the responsibility for planning and achieving their own objectives. The coach not only assists the coached in defining their aims but also in achieving them faster and more effectively than without the coach's help.

Fischer-Epe views coaching as a combination of individual counselling, personal feedback and practice oriented training. People start considering the possibility of coaching after they have failed in searching for a solution to some problem. These critical situations can be described as the conflicts of roles and values (promotion at workplace, new technologies or 
procedures), critical situations and cooperation conflicts (problems at work) or the issues of personal development (problems in the course of changing or searching for a job) (Fischer-Epe, 2006, p.17-19). Most definitions of coaching can be summarized in the statement that coaching releases human potential. According to Palan (2002) a personality potential of a human being is a structured set of skills and abilities for the performance of some activity. The elements of human potential are usually classified into ability potential, qualification potential, value-oriented potential, socializing potential, and creative potential. The quality and quantity of human potential tend to be considered as basic elements of societal wealth.

The aim of coaching is improving the perception of reality and strengthening responsibility and self-confidence. The coached discovers facts with the coach's assistance rather than receiving them from the coach. It is essential that the coached may achieve results and aims set forth by him or her in the course of coaching. (Palán, 2002). Fleming claims that the essence of coaching is improving people's performance in what they are doing. As we can see, the idea that it is impossible to arrive at a uniform definition has been confirmed also in the case of coaching. However, for the purpose of the paper, we can indicate that coaching is assistance to people in the process of discovering their possibilities, while its principle is that the client (the coached) is made to reveal their hidden potential and solve problems through suitable questions. Since the clients reach the aim by themselves, the outcomes of the process will lead them to completely new and so far unknown possibilities.

The current period is accompanied with abundance of information and dynamic changes in the area of work performance; a continuous employee development is a basis of effective operation of the entire organization. Organizations need flexible and adaptable human resources, whose learning has to be oriented to the ability of fast adjustment to new conditions of work performance and turning out required work results. Coaching as a method has two advantages, namely:

- It is usually focused on the participant's personality as a whole, i.e. their knowledge and attitudes.

- The participant obtains "tailor-made" instructions and ideas, which enable a two-way communication and ensure that specific needs of the employee trained are respected.

Coaching represents a long-term leadership, explanation and regulation (rather than commanding). Activities between the coach and the employee are described in the long-term plan and harmonised with longterm objectives of an employee's career growth. The problem may arise in the requirements placed on the coach; after all, success very much depends on the coach's abilities to achieve that the participant attained the knowledge 
and skills required. Therefore, the coach has to be not only professionally but also pedagogically competent (in terms of andragogy), which places higher demands on the coach's selection or preparation.

Coaching is largely characteristic of an individual approach to education at workplace; it is often understood as individual counselling. It plays an important role in developing and improving knowledge, abilities in work performance. The coach creates part of the management process and participates in the following activities (Armstrong, 2007, p. 468):

- Ensures that people realize the nature of their work performance;

- Secures "controlled delegating", which means that people not only know what they are expected to do, but also that they knew and were able to realise their tasks;

- Asserts and promotes education;

- Stimulates people to deal with more demanding problems.

Coaching is most frequently used as a consulting firm for persons with decision-making authorities. It accompanies an everyday working life and supports optimisation of performance and managing abilities. Coaching applies the processes of investigating and self-discovering; it assists in shaping the client's awareness and willingness to accept responsibility, which is achieved by means of greater support and an active feedback. The aim is to render not only precise definitions of objectives but also achieve them faster and more effectively than without coaching. It may be described as a continual stimulation and orientation of the person educated towards achieving a desirable work performance and own initiative, while the person's individual features are taken into consideration.

This method can be used at the workplace or also outside it, e.g. in a training centre. Coaching may be introduced when work problems start to be pressing. However, it is used only in the case of critical behaviour or conflict or an unsatisfactory fulfilment of assignments, and in other situations which may render a negative signal. These circumstances could also be perceived as threats that could endanger a favourable process of coaching.

We can differentiate two types of approaches to introducing coaching. The first type of coaching can be used for dealing with one particular problem or a specific situation; the second one can be considered as part of the corporate culture; while it will be implemented on a current basis, and its aim is to prevent from the rise of negative situations and this way contribute to development and learning. Coaching may be conducted on an individual basis, while all the questions are solved directly with the coached person; all problems that occur during the fulfilment of objectives are jointly discussed. The coached persons are assisted also in the 
preparation for screening tests. They can meet their coach in the group coaching, where problems are solved in a team.

These roles of coaches were identified by means of research carried out by the International Coach Federation, IFC). The highest number of those addressed view their coach as a mentor and business consultant. A smaller number perceive coaches as teachers, assignment setters or as intellectual leaders. Each organisation that opts for coaching also expects results and benefits, which may be summarized as follows:

- Self-awareness;

- Better target setting;

- More balanced life;

- Lower stress level;

- Improved self-discovery;

- Improved self-confidence;

- Higher quality of life;

- Improved communication skills;

- Higher rate of finished projects;

- Improvement of health condition;

- Better relationships with colleagues;

- Better family relationships (O’Neill - Broadbent, 2003, p. 77 - 80).

Coaching may be also described as a process of asking suitable questions aimed at unblocking man's potential, so that this released potential may be utilised in achieving required performance.

The coaching process contains four basic steps:

Preparation - the first step to coaching is observation. For coaching to make sense, the coach has to recognise strong and weak points of the coached and the way the coach cooperates with colleagues as well as their ability to reach objectives;

Discussion - the main aim of coach's discussion with the coached is to design a plan, containing strategies, through which aims are achieved; coaching - overcoming performance problems and building skills;

Active coaching - an effective coach offers ideas and advice. Providing and accepting the feedback is a key element of an active coaching;

Further monitoring - the progress of the coached is monitored, which ensures that the manager does not go astray of the path towards increasing performance. In case that happens, the monitoring enables the coach to make remedial adjustments (Harvard Business Essentials, 2004, p. 16).

Coaching contributes to overcoming performance problems, to skills development, increase in productivity, to the preparation of career growth, to improvement of an organisation's possibilities to maintain its managers and to improve the organization culture. 


\section{Methodology Starting Points and Results of Empirical Research into Coaching Implementation:}

Well-known corporations as for instance Dell, IBM or Motorola, which use coaching as an instrument of developing their managers and employees, confirm that it is worthwhile investing in this method of their employees' development. (Williams, 2007). Similarly, coaching is used in institutions providing services, as well as in those providing health care.

The research in the possibilities of increasing human resources performance by means of education covers a large problem area and necessitates to do research in several stages. We present here only some partial results. Respondents were human resources with complete secondary education with the final examination referred to as "maturita" and higher (university) education (of all the three levels), who perform professional and managerial jobs in $\mathrm{N}$ - category Health Service and Welfare Service (Code 85) and in the category of E - Pharmacies. Respondents were selected on a random basis and had to meet the following criteria:

- Education completed: complete secondary school education closed with the maturity final examination and higher (university) education;

- Activity performed, namely:

o Professional jobs, either in specialist or in creative jobs/tasks performed mainly by graduates from health service fields of study.

o Managerial tasks

- line management level;

- mid-level management;

- top management level;

- business owners.

The research was conducted by means of the interview method and the questionnaire method. The data collection was held in two stages and several rounds (within each stage), so that the content of required information value and containing opinions of respondents may be acquired from the given number of respondents by means of the mentioned methods. Respondents were selected from N - category of the Statistical Branch Classification of Economic Activities with the following Branch classification of economic activities (OKEC) codes: G-code 52310 Pharmacies (Coll. No. 552 BY-LAW of the Office for Statistics, Slovak Republic of 12 September 2002, which publishes the Statistical Branch Classification of Economic Activities): 


\begin{tabular}{|c|c|}
\hline $\begin{array}{c}\text { Branch classification of } \\
\text { economic activities } \\
\text { (OKEC) Code }\end{array}$ & Name: Branch Classification of Economic Activities \\
\hline 85000 & Health service and welfare service \\
\hline 85100 & Health service \\
\hline 85110 & Activities of hospitals \\
\hline 85120 & Activities of outpatient medical practice \\
\hline 85130 & Activities of dental medical practice \\
\hline 85140 & Other activities in health service \\
\hline 85141 & Health service hygienic service for human body \\
\hline 85149 & Other activities in health service \\
\hline 85300 & Welfare service activities. \\
\hline 85310 & Welfare service activities with accommodation \\
\hline 85320 & Welfare service activities without accommodation \\
\hline & Pharmacies \\
\hline 52310 &
\end{tabular}

The sample was made up from 96 respondents from state-owned (46) and private institutions (50), which employ various numbers of employees, ranging from micro-institutions (employing ten employees at most) up to large organizations. It was those respondents from the initial sample of 200 respondents (from proportionately represented in state-owned and private institutions) who confirmed that coaching was applied in their organizations. Individual employees of these enterprises form statistical units and their opinions are the basis for the application of selected statistical methods, which will enable us to evaluate the problems analyzed.

Tab. 1 Application of coaching by institutions employing respondents of the research

\begin{tabular}{|c|c|c|c|}
\hline $\begin{array}{c}\text { size } \\
\text { Institution type }\end{array}$ & $\begin{array}{c}\text { Institution up to } \\
10 \text { employees }\end{array}$ & $\begin{array}{c}\text { Institution up to } \\
\text { 49 employees }\end{array}$ & $\begin{array}{c}\text { Institution over } \\
50 \text { employees }\end{array}$ \\
\hline State institutions & 9 & 11 & 26 \\
\hline Private institutions & 6 & 15 & 29 \\
\hline
\end{tabular}

Source: own processing

Our empirical research is based on the characteristics of coaching types presented by Fabianová and Janeková (2011):

- Individual work coaching focuses on the development of soft skills. It is suitable for all the positions in management and for the development of skills in services. In this type of coaching, the coach meets the coached regularly in person; the coached sets forth personal objectives and searches for paths leading to their achievement.

- Group coaching. External or internal coach coaches a group of individuals, who are in the same or comparable functional positions (e.g. heads of sections/departments, chief physicians, and the like). 
- Team coaching. It is suitable for work teams that participate in joint tasks or projects. It is efficient for starting teams or as an instrument of team cooperation processes.

These two types of coaching can be further subdivided in terms of their purpose/ focus, namely:

- Coaching focused on talents;

- Coaching in organizational change;

- Creativity coaching;

- Coaching in dealing with conflicts;

- Time management coaching.

These specific types of coaching can help in dealing with specific problems, either work-related, or with organizational changes.

Tab. 2 Selected types of coaching classified into individual, group and team coaching

\begin{tabular}{|c|c|c|c|}
\hline $\begin{array}{c}\text { Types of } \\
\text { coaching by } \\
\text { numbex of participants }\end{array}$ & $\begin{array}{c}\text { Individual work } \\
\text { coaching } \\
\text { Types of } \\
\text { coaching by focus }\end{array}$ & Group coaching & Team coaching \\
\hline $\begin{array}{c}\text { Talent-focused } \\
\text { coaching }\end{array}$ & 17 of 96 & 96 of 96 & 26 of 96 \\
\hline $\begin{array}{c}\text { Organizational change } \\
\text { coaching }\end{array}$ & 87 of 96 & 94 of 96 & 89 of 96 \\
\hline Creativity coaching & 35 of 96 & 31 of 96 & 0 \\
\hline $\begin{array}{c}\text { Dealing with conflict } \\
\text { coaching }\end{array}$ & 21 of 96 & 38 of 96 & 42 of 96 \\
\hline $\begin{array}{c}\text { Time management } \\
\text { coaching }\end{array}$ & Source $0 w n$ rocess & \\
\hline
\end{tabular}

Source: own processing

Table 2 shows relations between the coaching by the number of participants and the coaching by focus. It is interesting to observe that talentfocused coaching is most frequently applied in group coaching; individual work coaching is used in times of organizational changes. In all the three types of coaching by the number of participants, the focus is on coaching for creativity, while creativity is developed in almost all organizations in which the research was conducted.

Apart from work coaching, we can describe an individual personal coaching, which is used in the course of changes in life, when coping with relationships problems, in the case of loss of motivation or health problems, as well as for the purpose of stress prevention (Fabianová and Janeková, 2011).

Stacke extends the offer of coaching by coaching changes in organizations, where the focus is not only on mastering the change 
management but also on the know-how specific for coaching according to the scope of change (Stacke, 2005, p. 30).

Individual and group coaching are both subdivided into external and internal types. The external coach comes from the organization's external environment, and as a rule is an ICF member or member of another organization associating coaches. The external coach can be referred as "the change agent"; his or her strength is its extensive training and understanding coaching problems. Further, this coach is unbiased, has a lot of experience and most importantly is able to openly communicate across hierarchical structure, while the coach's main strength is impartiality. Weak points of the external coaching include high costs. Costs of professional coaching range according to the coach's qualification and experience in coaching groups on the average EUR120-240 per a session. In the case of coaches working with individuals, the price range is usually from EUR20 to EUR60 EUR per session (Medvec, 2011). However, the price for service depends on the group size and type of coaching. Other costs of coaching of this type are included in the payment of wages for the hours that employees have actually not worked but spent the time at meetings with the coach.

The internal coach is undoubtedly more advantageous for the firm. Apart from that, the internal coach is familiar with the setting in which he or she performs the task, which may be an advantage but also an obstacle because this coach might not deal with problems impartially. On the other hand, the coaching by internal persons appears to be more natural and enables to follow an immediate development of persons coached. Internal coaches are usually managers, executives, or employees who are viewed by the employer as promising persons. They usually take only several days' training; consequently, their expertise cannot be compared with that of external coaches. The most demanding is perhaps the manager's role as a coach, as it requires closer relationships with people. This interactive process is based on three elements: technical assistance, personal support and individual challenge. These elements also include emotional links, which have to ensure the effectiveness of coaching. One session usually lasts no longer than three hours. On a regular basis, the entire process closes after three up to six months, which accounts for from ten to twelve sessions (Luecke and Ibarra, 2006). The length of coaching can be set as needed and in accordance with the aim set forth.

\section{Conclusion from Research and Proposals for the Development of Coaching: \\ Our analysis indicates}

a) coaching is applied as an effective method of employee further education in all types of organisations by size; 
b) the most frequently applied type of coaching by focus is the creativity coaching, which is practised in all the three types of coaching by the number of participants.

Coaching releases human potential and enables to increase its performance; it represents a non-directive method of leadership, which is based on the development of activity, an individual's independence and creativity and promotes a better utilisation of this potential.

Essential principles of coaching are based on a natural human behaviour with all the aspects that affect this behaviour. For this reason, we perceive coaching as an effective method of personal and professional development.

In the context of managerial practice, coaching may be defined as one of the tools of leading people. Paul Hersey and Kenneth Blanchard in situational leadership (Majtán, 2009) introduce a new variable, namely maturity; based on the level of maturity the manager should choose a suitable leadership style corresponding to subordinates' maturity. Apart from work maturity, Hersey and Blanchard also describe psychological maturity. The style of leading subordinates changes in terms of the level of work achieved and psychological maturity. Therefore, we can differentiate between formal and managerial coaching. Managerial coaching is a specific form of coaching, in which the manager - coach utilises instruments of formal coaching and those for leading subordinates. In order to ensure the application of coaching at workplace, it is suitable to perceive this method in a wider context, be familiar with the principles and sources of coaching and based on that, view coaching in terms of its application. An essential idea of coaching is that the coached has at their disposal some potential and is able to increase their performance owing to this potential. Without this required potential, one cannot be a coach. Distrust, either one-sided or on both sides, in any area of coaching refrains from achieving the best results. An equally important element of coaching is ethics. Rules of ethics have to be observed mainly to build the trust between the manager and the subordinate. This can help not only within coaching, but also in the overall manager - subordinate relationship. At the same time, managers declare in this way they respect their environment, trust their team and believe in the capabilities of their subordinates. This way they set an ethical standard, which they transfer to their subordinates.

In management, advantages of coaching rest in the fact that the client learns to believe in themselves, rely on their own decisions, take over responsibility for themselves. Coaching mainly leads to increasing the coached person's self-confidence and arouses the joy of learning. In management, the advantage of coaching may mainly be seen in higher performance and productivity of employees. In order to achieve favourable 
results in coaching, we have at first overcome barriers that can arise on the side of the coached or also on that of the coach. These barriers may include prejudice, expectations, inferiority or superiority feelings, unfavourable first impression, or also differing communication styles or means of expression. In the literature on the subject, we can find various names denoting the coach, e.g. mentor or trainer.

We can agree on that not everybody is ready to perform the function of coach. The coach should have some abilities and features of character. Coaches should be impartial and fair-minded and should not find it difficult to speak their mind. In our opinion, every coach should be familiar with at least essential facts about communication, psychology and management, and their work and life experience are a great asset. Of no small importance is also the coach's emotional maturity, self-reflection, self-control, and social competences, in particular as far as establishing contacts is concerned, as well as team work and conflict management. Finally, it is vital for the coach to like people.

\section{References:}

Armstrong, M. (2007). Řizení lidských zdrojů. Praha : Grada Publishing. Čihovská, V. et al. (2000). Manažment obchodnej firmy. Bratislava : Publ. Ekonóm, 2000.

Fabiánová, J. and Janeková, J. (2007). Koučing ako nástroj zvyšovania l'udských zdrojov. noviny [online]. 11.6.2007 [cit. 2011-10-20]. Available at: https://www.sjf.tuke.sk/kpiam/TaIPvPP/2008/index.files/Ekonomika_a_man azment/fabianova-janekova.pdf.

Fischer-Epe, M. (2006). Koučováni: zásady a techniky profesního doprovázení. The first edition, Prague: Portál.

Fleming, I. and Taylor, A. J. (2005). Koučování. The first edition. Prague : Portál.

Harvard Business Essentials: Coaching and Mentoring: how to develop top talent and achieve stronger performance. (2014). Boston : Harvard Business School, Press.

International Coach Federation. (2012). Coach Referral Service. ICF

International Coach Federation [online]. Lexington, KY: International Coach Federation, 2011a [cit. 2012-02-11]. Available at:

http://www.coachfederation.org/clients/crs/.

Kazdová, A. (2008). Koučinkový boom ve firmách: módní vlna nebo nutný trend? HRM: Human Resources Management, 4(4), 38-40.

Luecke, R. and H. Ibarra. (2009). What Coaching Is All About. Its Place In Management [online]. Boston : Harvard Business School, [cit. 2012-02-12]. 16 p. Available at:

http://managingprogrammers.com/papers/RoleOfCoaching.pdf. 
Majtán, M. et al. (2009). Manažment. Bratislava : Sprint dva.

Medvec, P. (2011) Neplet'te si kouče s vědmou. KarieraWeb.cz [online]. Praha: Economia, 25.8.2011 [cit. 2011-11-12]. Available at: http://kariera.ihned.cz/c3-52656000-q00000_d-neplette-si-kouce-s-vedmou.

O’Neill, T. and Broadbent, B. Personal Coaching: This coach is for you. $T$ $\& D, 57(11), 77-80$.

Palán, Z. (2002). Lidské zdroje: výkladový slovník. The first edition. Prague: Academia.

Pokojná, K. (2008). Dobrý kouč nerozdává rady. Trend: 27 February 2008. REGISTR KOUČU ČR. (2006). Jak vybrat správného kouče. Registr koučů $\check{C} R$ [online]. Praha: Koučink Centrum, 2006 [cit. 2011-11-01]. Available at: http://www.koucove.cz/jak-vybrat-kouce.

Stacke, E. (2005). Koučování pro manažery a firemni týmy. Prague: Grada. Whitmore, J. (2004). Koučování: rozvoj osobnosti a zvyšování výkonnosti. The second extended edition. Prague: Management Press.

Williams, R. (2007). The second-fastest growing profession. International Coach Federation. Updated on 04 April 2007. 